\title{
Characterization and Shear Strength Prediction of Reinforced Concrete Deep Beams - A Review
}

\author{
Kwadwo Adinkrah-Appiah ${ }^{1}$, Mark Adom-Asamoah ${ }^{2}$ \\ ${ }^{1}$ Sunyani Polytechnic, Department of Civil Engineering, Sunyani, Ghana \\ ${ }^{2}$ Kwame Nkrumah University of Science and Technology (KNUST), Department of Civil Engineering, Kumasi, Ghana
}

\begin{abstract}
Reinforced concrete deep beams are structural elements that transfer heavy gravity loads predominantly through shearing action to their supports. A significant feature of deep beams is their high shear strength. This is attributed to the internal tied-arch mechanism which conveys the load directly to the supports through concrete compressive struts. Different definitions have been proposed for $\mathrm{RC}$ deep beams by various researchers and codes of practice that differ in concept.Also, various shear strength prediction models have been developed by several researchers and codes for the estimation of the shear strength of deep beams through analytical and extensive test programs. However, there seems to be no agreement on which definition adequately classifies what a deep beam is and which model produces best results close to experimental values, the shear strength of this class of beams. The study compared the definitions and evaluated the shear capacity models of deep beams per different code provisions based on data from 210 deep beams obtained from the literature. It was found that the ACI-318 (2008) code definition concept gives the most realistic characterization of a deep beam, whilst its shear strength model, based on the strut-and-tie model approach, provides the best prediction for the shear strength of a deep beam.
\end{abstract}

Keywords: Deep beams, Shear strength models, Strut-and-tie model, Average margin of safety, Tied-arch mechanism

\section{Introduction}

Reinforced concrete (RC) beams generally exhibit low resistance to shear when the depth of the beam increases [1]; [2]; [3]. This phenomenon is known as the size effect[4]; [3]. However, it is also confirmed through experimentation that irrespective of the depth of RC beam, when the shear spanto-effective depth ratio $(\mathrm{a} / \mathrm{d})$ reduces, the shear strength of the beam increases [5]. This phenomenon leads to the classification of reinforced concrete beams into slender and deep beams [6].Areas in RC beams wherethe shear span is less than twice the member depth are found tobe dominated by tied-arch action rather than beam-action and are, hence, defined as D-regions (disturbed or discontinuity regions)[7]; [8]. Deep beams are characterized by the presence of one or more D-regions [9].

The design of RC deep beams,therefore, does not adhere to the elementary theory of bending based on the EulerBernoulli hypothesis, since the theory disregards the effects of shear deformation and stress concentration, and assumes that sections normal to the neutral axis before bending remain unchanged during and after bending. This implies that the transverse shear strain is zero, which in practice is not valid for deep beams. This assumption underestimates deflections in deep beams, where shear deformation effects are quite significant and hence under-estimate their shear capacity [1]. For instance, the shear capacity of a deep beam may be as much as two to three times higher than that predicted using conventional shear models developed for slender beams based on the Euler-Bernoulli hypothesis [2]

The elastic solutions on deep beams offer good description of their behaviour before cracking. However, after the development of a diagonal crack, significant redistribution of strains and stresses occurs and, therefore, the shear capacity of the beam must be predicted by nonlinear analysis. For a simply supported deep beam with a point load on top, the top load and bottom reactions produce large compressive stresses perpendicular to the beam axis. These stresses act together with shear stresses to form a complex stress field in the web. Because of the small horizontal distance between top and bottom load points (i.e. small a/d ratios), the outcome of such stresses result in a tied-arch action distinct in deep beams. Because of these complex stresses and strains, the study of deep beams has become a special area of interest.

Despite the complexities caused by the design of deep beams, the use of reinforced concrete deep beams has turned out to be more common in recent years. They often find their application in the design of transfer girders in high-rise buildings as well as foundation walls, bins, pile caps, water tanks, folded plate roof structures, floor diaphragms, shear walls and brackets or corbels[2]. Over the years, a variety of models have been proposed by many researchers and wideranging test campaigns have been undertaken on deep beams. Also, different definitions have been proposed to define RC deep beams by different researchers and codes of practice that differ in concept. However, there seems to be no agreement on which definition adequately classifies what a deep beam is, and which model produces best results close to experimental values, the shear strength of this class of beams.The objective of the study was to compare the definitions and the shear strength models forreinforced concrete deep beams given by different code provisions, and to suggest the most reliable code to appropriately define and predict the shear strength of deep beams subjected to loading.

\section{Definition of a Deep Beam}

There are several definitions given by various writers and standardsfor deep beams. [10]defined deep beams as beams with huge depths in relation to spans. In [11] Clause 29, a simply supported beam is classified as deep when the ratio of 


\section{International Journal of Science and Research (IJSR) \\ ISSN (Online): 2319-7064}

Index Copernicus Value (2013): 6.14 | Impact Factor (2013): 4.438

its effective span L to overall depth D is less than 2. Continuous beams are regarded as deep beams when the ratio $\mathrm{L} / \mathrm{D}$ is less than 2.5. The effective span is the centre-tocentre distance between the supports or 1.15 times the clear span, whichever is less. The Canadian code [12] states that the flexural member with a clear span $\left(l_{n}\right)$ to overall depth $(h)$ ratio less than 2 must be designated as deep beam and the non-linear distribution of strains should be taken into account.

According to [13], RC deep beam can be defined as a member with clear span equal or less than four times the overall member depth or regions of a beam loaded on one face with a concentrated load within twice the member depth from the support, and supported on the opposite face so that compression struts can form between the loads and supports. The [7] defines deep beams in clause 11.7.1 as members with effective length $\left(L_{n}\right)$ not greater than four times the overall member depth or regions of beams loaded with concentrated loads within twice the member depth from the support face, with the beam loaded on one face and supported on the opposite face so that compression struts can form between the loads and the supports.

[14]classifies deep beams as transfer beams and defines them as horizontal members that havea/d less than 2, which carry heavy gravity loads,predominantly through shear, by developing a diagonal crack. [6]define a deep beam as a directly loaded beam with a/d between 0.5 and 2.5. The writers also define shallow or slender beams as beams with a/d higher than 2.5 , whilst beams with a/d less than 0.5 fall into the category of corbels and brackets. They further characterize deep beams as beams that may develop tied-arch behaviour after the formation of inclined cracking which enables the beam obtain considerable reserve shear capacity. On the other hand, shallow beams are beams that may not develop significant arching behaviour and generally fail shortly after the formation of diagonal cracking unless shear reinforcement is applied. According to the writers, beams with a/d ratio lower than 0.5 fall under the category of corbels and brackets, and may not even develop inclined or diagonal cracking before they fail through a sliding or shear friction type of mechanism. The writers consider deep beams to be a transition between slender beams and corbels or brackets.

From the above definitions, there are two main concepts for defining deep beams: the [7] based definition and the[11] based definition. The [7] based definition classifies a RC beam as a deep beam based on two distinguishing parameters: geometry or loading condition. In terms of geometry, the [7] definition classifies a horizontal structural member as a deep beam when the ratio of its effective length $\left(\mathrm{L}_{\mathrm{e}}\right)$ to overall depth $(\mathrm{h})$ is less than or equal to 4 (ie. $\mathrm{L}_{\mathrm{e}} \leq$ 4h), as shown in Figure 1. In terms of loading condition, the ACI code classifies any beam as a deep beam when the entire beam or portions of it is loaded with a concentrated load within twice the member depth. This can further be explained by the presence of D-regions on the beam due to loading discontinuities irrespective of the beam's effective length to overall depth ratio [9].A D-region is a portion of a member within a distance of the depth of the beam $(\mathrm{h})$ from a force discontinuity or a geometric discontinuity[7].

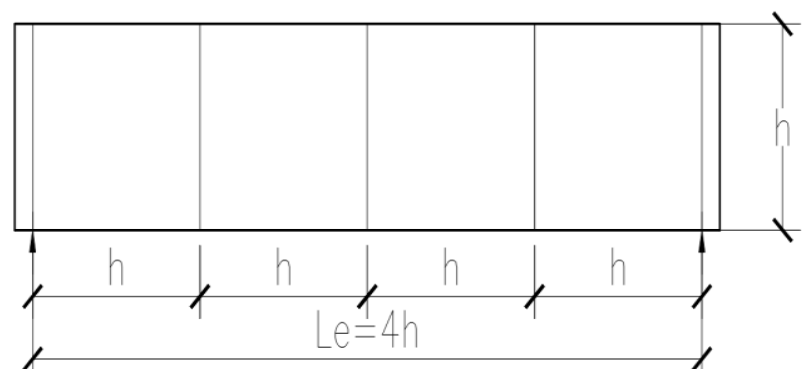

Figure 1: Deep beam definition by the [7]based on geometry

The ratio of the effective length to overall depth within 4 based on geometry prescribed by the ACI definition implies that, irrespective of the loading condition, there are four beam depths (h) that interconnect to form the length of the beam. This implies that if a central point load is placed on the beam, there will be two D-regions on each side of the load defined by two beam depths between the load and the supports (ie. $a_{v}=2 h$ ) as shown in Figure 2. This further implies that, a shear span of length $2 \mathrm{~h}$ exists between the load and each support which defines the two D-regions. On the other hand, if two symmetrical point loads are placed in the middle quarter of the beam as shown in Figure 3, then there exists two D-regions to each side of the loads defined by shear spans of less than two beam depths but more than one beam depth (ie. $\mathrm{h}<\mathrm{a}_{\mathrm{v}}<2 \mathrm{~h}$ ). Also, if the two symmetrical point loads are located in the first quarter of the beam, then there are two D-regions at each side of the loads defined by a shear span of less than one beam depth (h) between the loads and the supports (ie. $a_{v}<h$ ) as shown in Figure 4. This definition infers that no matter the type of loading on the beam, as geometrically defined by the ACI code, whether uniformly distributed or point loads, D-regions occur on the beam when the span is within four beam depths and hence it can be classified as a deep beam based on geometry.

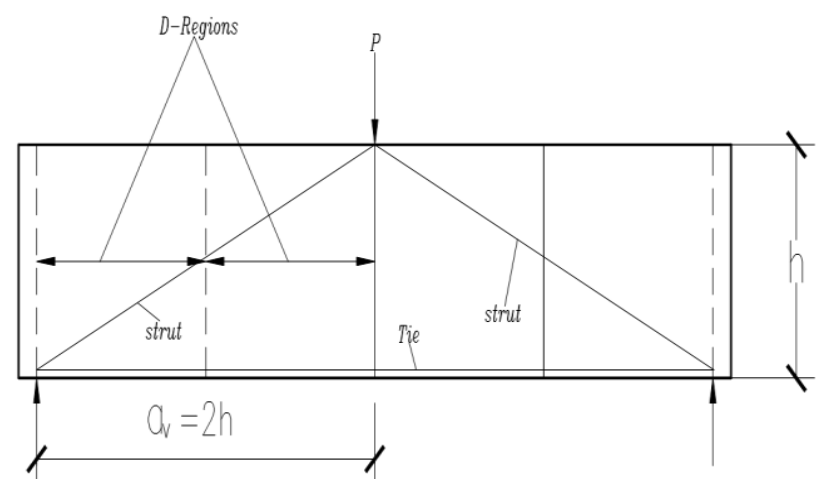

Figure 2: D-Regions defined by the [7]with a central-point load

For the other alternate ACI definition of a deep beam, the emphasis is on the mode of loading irrespective of the length of the beam. The load should be a point load and the distance between the load and at least one support reaction should be within twice the effective depth, which implies that the shear span should be at most twice the beam depth (ie. $a_{v} \leq 2 h$ ). This further implies that at least there should be two Dregions on one end of a beam which inter-connect to characterize it as a deep beam (Figure 5). This definition is also valid since the presence of D-regions on a RC beam 


\section{International Journal of Science and Research (IJSR) \\ ISSN (Online): 2319-7064}

Index Copernicus Value (2013): 6.14 | Impact Factor (2013): 4.438

produces non-linear strains, which is a major characteristic of a deep beam.

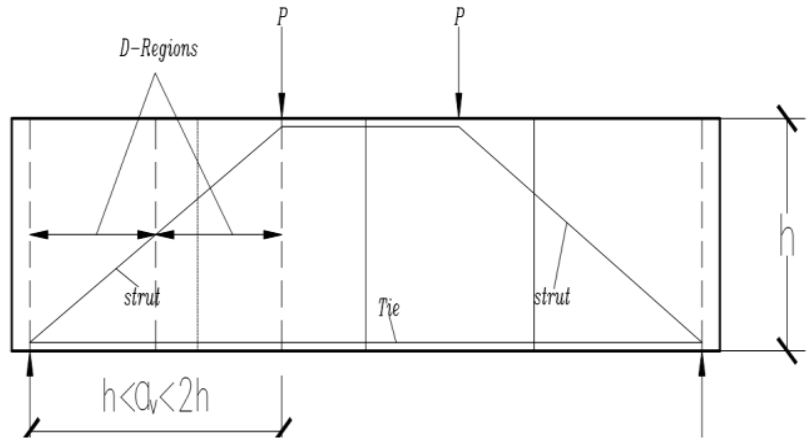

Figure 3: D-Regions defined by the [7]with two symmetrical point loads in the middle quarter regions

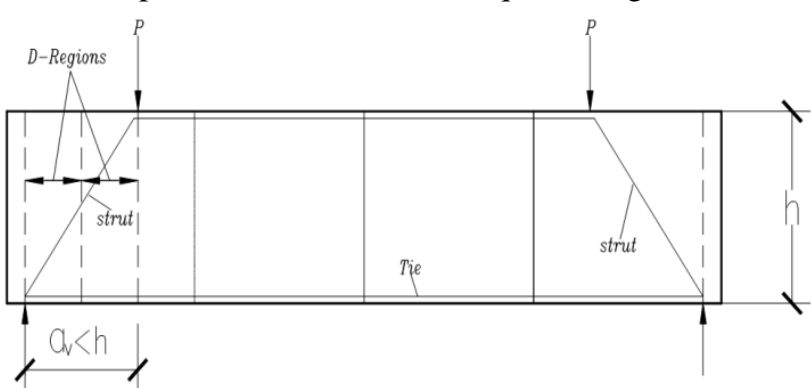

Figure 4: D-Regions defined by the [7]with two symmetrical point loads in the first quarter regions

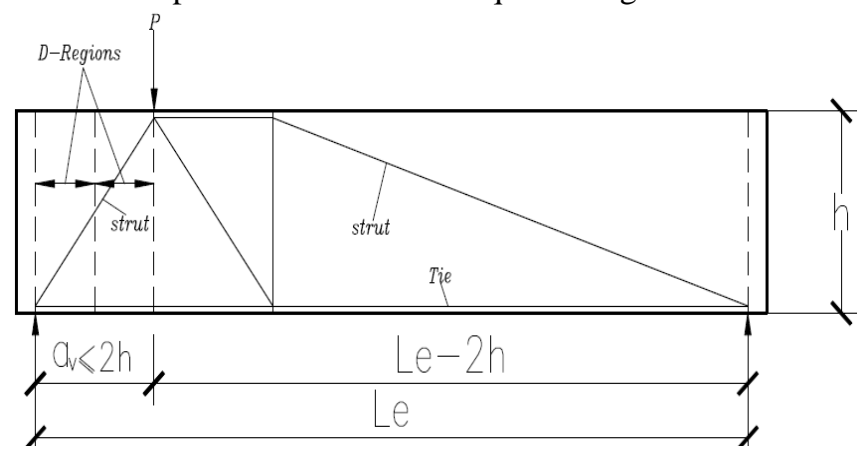

Figure 5: D-Regions defined by the [7]based on loading condition

On the other hand, the[11] based definition classifies a RC beam as a deep beam only in terms of geometry. And even in terms of geometry, the code classifies a RC beam as a deep beam when the ratio of its effective span to overall depth (h) is less than 2. Thus, even in terms of geometry, the ratio of effective span-to-overall depth of 2 implies that there are only two beam depths that interconnect to define the length of the beam (Figure 6). Now, when such a beamcarries a central point load, it will imply that there will be two Dregions at each side of the load defined by half of a beam depth or a shear span of one beam depth between the load and the supports (ie. $\mathrm{a}_{\mathrm{v}}=\mathrm{h}$ ) as shown in Figure 7. On the other hand, if the beam carries two symmetrical point loads, then the D-regions will be defined by a distance less than half of a beam depth or shear spans of less than a beam depth between the loads and the supports (ie. $\mathrm{a}_{\mathrm{v}}<\mathrm{h}$ ) as shown in Figure 8.

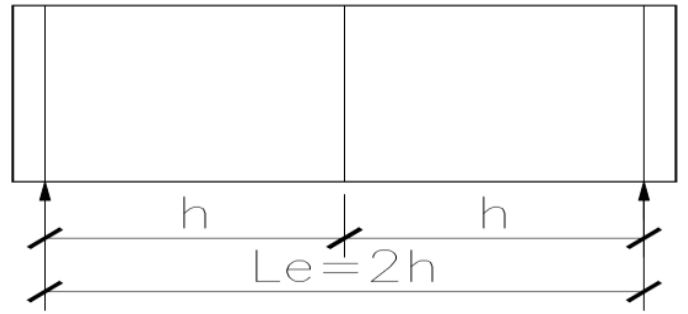

Figure 6: Deep beamdefinition by the [11]

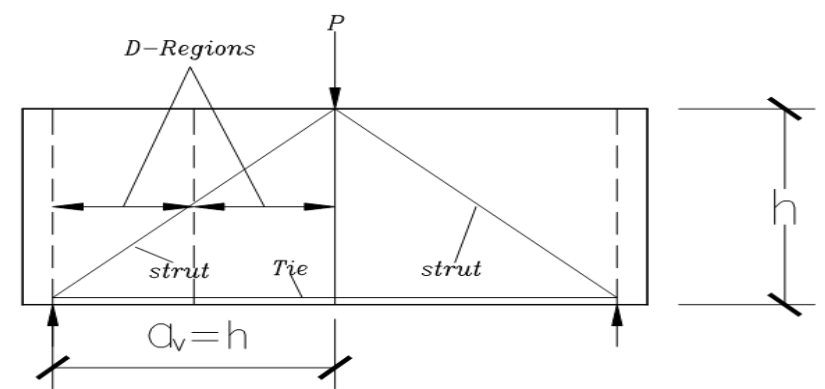

Figure 7: D-Regions defined by the [11]with a central-point load



Figure 8: D-Regions definedby the [11]with two symmetrical point loads

The[11] based definition implies that, in terms of loading condition, a deep beam consists of $\mathrm{a}_{\mathrm{v}} / \mathrm{h}=1$ (or $\mathrm{a}_{\mathrm{v}} / \mathrm{d}<1$ ) when the beam caries a central point load and $\mathrm{a}_{\mathrm{v}} / \mathrm{h}<1$ (or $\mathrm{a}_{\mathrm{v}} / \mathrm{d}$ is far less than 1 ) when it carries two symmetrical point loads. This definition is narrow since it excludes other possibilities of beam geometry where D-regions can exist on the beam such as when the beam span is made up of up to four beam depths, as prescribed by the [7] definition. Also, experiments carried out by many researchers have proved that a/d of up to 2 on a loaded RC beam produces non-linear strains in the beam due to the dominance of tied-arch action which transfers the load directly from the point of loading to the support through concrete struts; causing the beam to behave as a deep beam with increased shear capacity [15];[16]; [5]; [17].

Similar to the [11] definition, the [18] considers beams of clear span $\left(l_{0}\right)$ less than two times the effective depth as deep beams. The [18] does not provide specific design considerations for deep beams but only recommends that specialist literature should be contacted. It however recognizes the enhancement of the concrete shear strength $v_{c}$ in beams with sections that are closer to the face of a support or a concentrated load than two times the effective depth, $\mathrm{d}$ (Clause 3.4.5.8) and goes further to suggest a shear enhancement capacity fromv $v_{c}$ to $2 \mathrm{dv}_{\mathrm{c}} / \mathrm{a}_{\mathrm{v}}$. In a similar way, the [51]adopts an alternative approach by reducing the shear force due to loading within $2 \mathrm{~d}$ of the support by a factor of $a_{v} / 2 d$. This recognition of shear enhancement at sections 


\section{International Journal of Science and Research (IJSR) \\ ISSN (Online): 2319-7064 \\ Index Copernicus Value (2013): 6.14 | Impact Factor (2013): 4.438}

closer to a support or a concentrated load in RC beams contradicts the definition of a deep beam loaded with a central point load by the [18]. This is because a distance twice the effective depth at both sides of a central point load suggests that the total length of the beam cannot be less than four times the effective depth of the beam (4d) or four beam depths and not twice the effective depth as prescribed by the [18] definition.

\section{Factors Affecting Shear Strength of Deep Beams}

Several factors affect the shear strength of deep beams. Some of the most important ones include shear span-to-depth ratio, compressive strength of concrete, flexural reinforcement, vertical and horizontal shear reinforcement [19]. The contribution of each factor on the shear capacity of deep beams is discussed.

\subsection{Shear Span-to depth Ratio (a/d)}

The shear resistance of a deep beam fundamentally depends on its $\mathrm{a} / \mathrm{d}$. Various experimental studies have proved that the $\mathrm{a} / \mathrm{d}$ is the overriding parameter that affects the shear resistance of a deep beam, as the shear strength increases with a decreasing $a / d[20]$; [19]; [21]; [22]; [23]; [14]. This is because as the $a / d$ ratio decreases, the load is transferred directly by concrete struts, formed as a result of diagonal cracks, to the supports. This mechanism is known as the tiedarch or strut-and-tie action in deep beams [5]; [17]. In contrast to deep beams, slender beams are dominated by beam-action or mechanism as a/d ratio increases above 2.5 . In Figure 9, the STM plot represents the tied-arch action in deep beams and predicts the strength of deep beams very well when $\mathrm{a} / \mathrm{d} \leq 2.5$. The conventional sectional method rather predicts well the shear capacity of slender beams when $\mathrm{a} / \mathrm{d}>2.5$, compared to the experimental plot.

[8]tested 3 pairs of deep beams with a/d ratio of $0.94,0.76$ and 0.64 under two point loading. The results portrayed that as the a/d ratio decreased, the average values of the first crack load increased from 60.0, 69.5 to $78.5 \mathrm{KN}$ respectively. Similarly, the ultimate failure loads increased from $140.5,144.4$ to $149.1 \mathrm{KN}$ respectively, implying that as $\mathrm{a} / \mathrm{d}$ decreases in deep beams, their shear strength increases.

\subsection{Beam Span-to-Depth Ratio $\left(l_{n} / d\right)$}

[20]tested 12 deep beams having different span to depth ratios and concluded that, similar to $a / d r a t i o, l_{n} / d$ ratio also has a significant influence on the shear strength of a deep beam, with shear strength being inversely proportional to $l_{n} / d$ ratio. This is because as the $l_{n} / d$ ratio increases, a longer arch is formed to carry the load to the support and at the same time, the mid span deflection increases which creates more flexural cracking than shear failure[22].

\subsection{Beam Depth (Size Effect)}

The shear strength of a reinforced concrete beam decreases with increase in the depth of the beam. This phenomenon is prominently known as the size effect. The occurrence of size effect has been reaffirmed through several research efforts on slender beams - beams with a/d $\geq 2.0$ [25]; [26]; [4], [27]; [28]; [29]. Some analytical modelshave been proposed for assessing the size-dependent shear strength of such beams. [30]established that the critical strength of concrete beams decreases with increase in the beam depth, with a distinctive depth of $225 \mathrm{~mm}$ observed, above which the size effect phenomenon becomes evident. [26] also found from a series of tests that, the average shear stress to cause failure of the largest beam was only about one-third of that which caused failure of the smallest beam. This implies that, the shear strength of RC beams could reduce to as low as one-third of the strength of the beam with the lowest depth, as the beam depth increases, with all other parameters remaining constant.

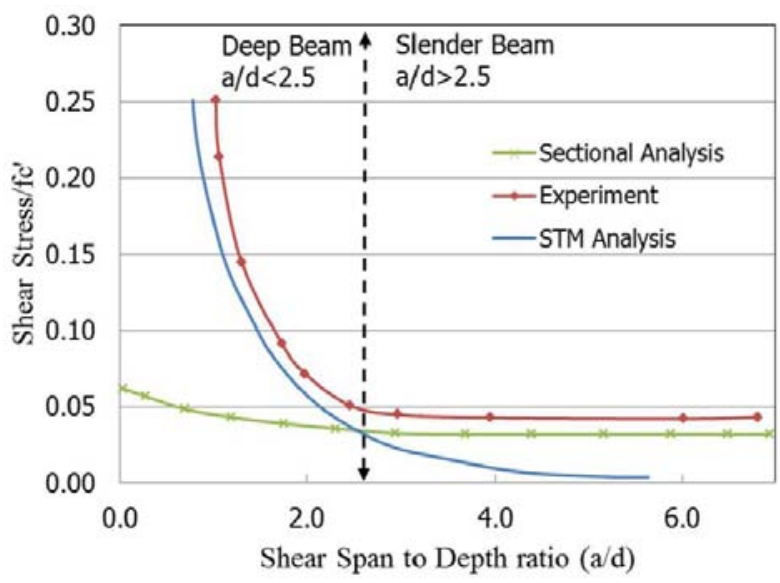

Figure 9: Variation of shear strength with $\mathrm{a} / \mathrm{d}[24]$

[31]tested twenty one beam samples to investigate the shear characteristics with different variable beam depths. It was found that an increase in beam depth results in more brittle failure with wide diagonal cracks and high energy dissipation rate related to size effect. Also, high strength concrete (HSC) deep beams have been found to exhibit more significant size effect with brittle behavior at failure.[32]concluded that HSC beams exhibit strong size effect in shear than normal strength concrete, which can be attributed to the fact that, failure of HSC normally occurs through the aggregate particles, reducing the aggregate interlock component of the shear strength of the concrete.

Many fracture mechanics models have been suggested in order to describe the failure of concrete [33]; [34];[35]. Each of these models establishes some material fracture characteristics regardless of the structural geometry and size. Concrete structures demonstrate size effect which has been explained as a result of the randomness of material strength. In large structures it is more likely to meet a material point of lesser strength. Nonetheless, size effect in concrete structures must be explained by a non-linear form of fracture mechanics that considers the localization of damage into a fracture process zone (FPZ) of a non-negligible size. [36]was the first to develop a size effect law using infinite series, and restraining its applicability to the size range of $1: 32$. Thus, the phenomenon of size effect has strongly been confirmed in beams and has been considered by some shear predictive models [18]. 


\section{International Journal of Science and Research (IJSR) \\ ISSN (Online): 2319-7064 \\ Index Copernicus Value (2013): 6.14 | Impact Factor (2013): 4.438}

\subsection{Beam Web Reinforcement}

Vertical web reinforcement is one of the major factors that significantly affect the shear strength of deep beams, aside the a/d ratio. The fundamental purpose of vertical web reinforcement is to give confinement to the concrete which helps to improve the shear capacity of deep beams. Also, vertical reinforcement improves the shear strength of deep beams more effectively than horizontal shear reinforcement, and in the case of shear failure vertical reinforcement makes the beam fail in a more ductile manner [14]; [37]. Many studies have revealed that the shear strength of a deep beam increases linearly with increase in the vertical shear reinforcement [38]; [25]; [39]; [19];[40]; [22]; [41]. However, [19] found that the contribution of the vertical shear reinforcement diminishes as the $a / d$ decreases $(a / d<1)$. A similar study by [23] confirmed that the higher the $a / d$ ratio $(a / d>0.75)$, the higher the contribution of the vertical web reinforcement. On the contrary, [14] has found that the shear strength increase with vertical shear reinforcement isobserved up to a reinforcement ratio of $1.25 \%$, above which there is no effect. This implies that the contribution of vertical shear reinforcement to the shear strength of a deep beam is not infinite, but has a limit.

Some studies have revealed that the horizontal shear reinforcement has no effect on the shear strength of deep beams [39]. However, other studies found that there exists a little increase in shear strength with the increase of horizontal shear reinforcement. This is specifically so when there is low vertical shear reinforcement. On the contrary, in the presence of more vertical reinforcement, an increase in the horizontal shear reinforcement ratio will not have any appreciable contribution on the shear strength of the beam [19].

\subsection{Type of Concrete}

[42]conducted a study to compare the shear behavior and performance of deep beams made with a moderately highstrength self-compacting concrete (SCC) of strength $50 \mathrm{MPa}$ and a corresponding normal weight concrete (NWC). Two sets of beams were tested for both SCC and NWC, one set with congested (closely spaced) shear reinforcement and the other with non-congested (widely spaced) shear reinforcement. The writers concluded that the SCC deep beams with relatively non-congested web reinforcement showed a slightly higher loadcarrying capacity in terms of diagonal shear cracking and ultimate loads compared to the NWC samples.

[43]studied the aggregate interlock contribution to the shear strength of lightweight concrete, with different aggregate sizes in continuous deep beams. They found that even though the pattern of the failure plane of the samples tested was scarcely influenced by the maximum aggregate size and type of concrete, the diagonal crack size along the failure plane reduced with the increase of the maximum aggregate size and was much lower in normal weight concrete than in lightweight concrete deep beams at the same loading levels. It was also established that the gradual reduction in stiffness after the occurrence of a diagonal crack was more pronounced in deep beams made of lightweight concrete than in normal weight concrete deep beams, and increased with the reduction of the maximum aggregate size.

\subsection{Compressive Strength of Concrete $\left(f_{c}^{\prime}\right)$}

The shear strength of a deep beam is a function of the compressive strength, $f_{c}^{\prime}$. [44] showedthata $45 \%$ increase in $f_{c}^{\prime}$ is accompanied by a $10 \%$ shear increase. This increase is not proportional since in the case of high strength or lightweight concrete, the fractured aggregates at ultimate load will generate less friction compared to normal strength concrete. Similarly, [19] study on deep beams showed that $f c^{\prime}$ has a great influence on the shear capacity. Their results showed that the shear capacity is higher in the case of deep beams with high $f_{c}$ ' and low web reinforcement, compared to a beam with low $f_{c}$ ' and high web reinforcement. However, the tests conducted were limited to only normal strength concrete $\left(f c^{\prime}=16\right.$ to $\left.23 \mathrm{MPa}\right)$. On the other hand, [14] has found that the compressive strength of concrete $\left(f c^{\prime}=24\right.$ to $37 \mathrm{MPa}$ ) has only a little influence on the shear capacity of deep beams.

\subsection{Longitudinal Reinforcement}

[21]tested 64 deep beams and found that with the increase of longitudinal reinforcement, the shear strength of a deep beam increased significantly. Similar studies by [23] and [14] found that the longitudinal reinforcement has linear correlation with the shear strength up to a certain limit for deep beams without shear reinforcement and beyond that it has no effect. Longitudinal reinforcement increases the shear capacity of a deep beam by reducing the crack width, improving the interface shear transfer mechanism and increasing the dowel action [14]). [37]has shown that the average shear strength increases linearly as the longitudinal reinforcement ratio increases up to $1.5 \%$ and beyond that it reaches a plateau.

[45]also showed that the failure of deep beams with longitudinal reinforcement less than that suggested by [46] $\left(A_{\text {st.min }}=\frac{3 \sqrt{f c}}{f_{y}} b_{w} d\right)$ is flexural and is accompanied by large deflections without any inclined cracks. The writers further observed that as the flexural tensile steel reinforcement increases, the failure due to cracking of the concrete at nodal zones becomes evident.

\section{Shear Strength of RC Deep Beams}

Research has proved thatdeep beams transfer shear through either a tied-arch mechanism or truss (beam) mechanism (Figure 10). The two most influentialparameters affecting the type of load transfer mechanism are the $a / d$ and the amount of transverse reinforcement. It has been confirmed thatas a/ddecreases, a higher fraction of load is transferred through tied-archaction, which imparts higher shear strength in the beam as a result of direct transfer of the load from the loading point to the support through compressive struts (Fig. 10a). Conversely, beams with higher a/dratiostransfer a larger portion of loads through beam or truss action (Figure 10b)[47];[48]. 


\section{International Journal of Science and Research (IJSR) \\ ISSN (Online): 2319-7064}

Index Copernicus Value (2013): 6.14 | Impact Factor (2013): 4.438

Similarly, higher amounts of transverse reinforcement lead to a larger fraction of the load to be transferred bytruss action, although at very low a/d ratios, the effect of transverse reinforcement diminishes [23]; [19]. On the other hand,a certain minimum amount of web reinforcement (verticaland horizontal) is required to avoid splitting of diagonal struts that form between loads and supports of deep beams which give them enhanced shear capacity [5].

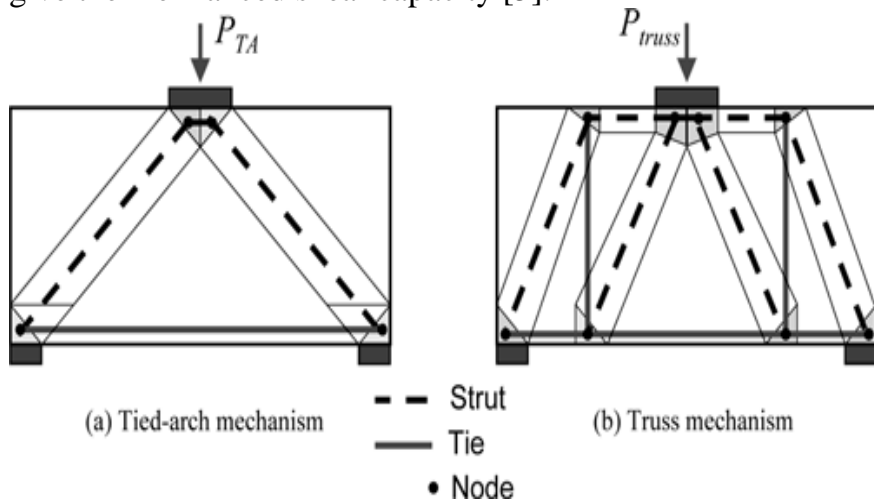

Figure 10: Load transfer mechanisms in deep beams

Failure of deep beams is generally through crushing of concrete in either reduced region of compression zone at the tip of inclined cracks, which is known as shear compression failure, or by fracture of concrete along the crack referred to as diagonal splitting failure [49]. In deep beams with shear span-to-depth ratio of less than 2.5, there is reserved energy in the post-cracking region, which results in less brittle failure [50].

The failure of deep beams manifest in four modes identified as diagonal splitting (shear) failure, shear-compression failure, shear-flexure failure and flexure. The diagonalsplitting failure, characterized as shear failure, is brittle, sudden and hence treacherous. A critical diagonal crack, which joins the loading point at the top and support point at bottom of the beam, develops through which failure occurs. In the shear-compression failuremode, after the inclined crack appears, the concrete portion between the load point and the support experiences high compression and finally fails. This failure mode is equally a brittle mode of failure. The shear-flexure failure mode is a combination of shear and flexure. Flexural cracks form first followed by the partly diagonal cracks. This is ductile mode of failure in which the beam deflects at the centre and no explosive sound is heard at the time of failure [14].

\section{Models for Shear Strength Prediction in Deep Beams}

Several predictive models have been suggested by various researchers and many codes of practice have validated some of these models for design of RC deep beams. Generally, since deep beams are characterized by small a/d ratios, failure usually occurs by shear compression or diagonal splitting in which the concrete between the support and the loading point fail in compression after a diagonal crack. Thus, the failure of deep beams is characterized by tied-arch action instead of beam action, which makes deep beams exhibit higher shear strengths. It is therefore anticipated that, predictive models which account for the mode of failure or type of load transfer mechanism at failure will produce more realistic results.

Seven different models were assembled for analysisin the study as outlined in Table 1 to find the most realistic ones for the prediction of the shear strength of RC deep beams. The performance of each model was assessed, by comparing the Average Margin of Safety (AMS) as well as their coefficients of variation (CV), to find out their predictive powers relative to the experimental results obtained from the data base in the literature of deep beams. The shear equations endorsedby the following codes of practice were assessed: the Strut-and-Tie model (STM) proposed by the American Concrete Institute [7];Indian Standard,[11]; [18]; [46]; [51]; [52] and [53].

Among the shear models considered, the STM is the only method that predicts the shear strength of deep beams by recognizing the load transfer mechanism through consideration of the strength of the concrete struts that are formed during failure of deep beams. The rest of the models rather depend on combination of some of the individual component parameters of the beam such as shear span-todepth $(a / d)$, concrete strength $\left(f_{c}^{\prime}\right)$, beam span-to-depth $\left(l_{n} / d\right)$, beam size (d) and amount of flexural reinforcement $\left(\rho_{t}\right)$, to predict the shear strength of the beam without recourse to the load transfer mechanism.

\section{Results and Discussions}

A total of 120 reinforced concrete deep beams were gathered from the literature, with 116 of them without shear reinforcement whilst 94 had shear reinforcement (Table 2 and 3). Table 4 depicts the results of the predictions of the various models compared to experimental results of deep beams without shear reinforcement; whilst Table 5 covers the results of deep beams with shear reinforcement. The highest average margin of safety (AMS) value means the most conservative model; the least standard deviation (STD) suggests a significant improvement in the prediction uniformity whilst the lowest Coefficient of Variation (CV) implies that a particular data set has the lowest variation in the accuracy, hence the greater uniformity in prediction [54].

For the results presented, the [7] STM model generated an AMS that was most economical and safe for the deep beams without reinforcement. It produced an AMS of 1.1 compared with the [51], [18] and [11], which produced AMS valuesof $1.9,4.4$ and 4.5 respectively. Thus, in terms of accuracy and safety, the [7] STM model proved superior to the rest of the models whichcan be described as overly conservative since their AMS values are far higher to 1. The [7] STM also generated the lowest $\mathrm{CV}$ of 0.36 compared to $0.38,0.41$ and 0.42 produced for each of the other three models namely; [11], [18] and [51]respectively. This suggests that in terms of prediction uniformity, the [7] STM proves superior among these set of models as a result of its lowest CV. On the other hand, the [6], [53] and [52] design equations with AMS of $0.8,0.4$ and 0.4 respectively, over-estimate the shear strength of deep beams without shear reinforcement and are not reliable for design in terms of safety. This trend of AMS results is similar to values obtained in a study carried out by [14]. Again, the [7] STM gives the best 
International Journal of Science and Research (IJSR)

ISSN (Online): 2319-7064

Index Copernicus Value (2013): 6.14 | Impact Factor (2014): 5.611

Table 1: Shear Strength Predictive Models

\begin{tabular}{|c|c|c|c|}
\hline No. & Author & Model & Remarks \\
\hline 1. & $\begin{array}{l}\text { ACI-318 } \\
\text { STM } \\
(2008)\end{array}$ & $\begin{array}{c}F_{n s}=f_{c e} A_{c e} \\
f_{c e}=0.85 \beta_{s} f_{c}^{\prime} \\
F_{n t}=A_{t s} f_{y} \\
F_{n n}=f_{c e} A_{n z} \\
f_{c e}=0.85 \beta_{n} f_{c}^{\prime} \\
V_{u}=\min \left\{\begin{array}{l}F_{n s} \sin \theta \\
F_{n n} \sin \theta\end{array}\right.\end{array}$ & $\begin{array}{c}\mathrm{F}_{\mathrm{ns}}=\text { nominal compressive strength of concrete strut, } \\
\mathrm{F}_{\mathrm{nt}}=\text { nominal strength of a tie, } \\
\mathrm{F}_{\mathrm{nn}}=\text { nominal compressive strength of a nodal zone, } \\
\mathrm{A}_{\mathrm{cs}}=\text { the smallest effective cross-sectional area of a strut, } \\
\mathrm{A}_{\mathrm{ts}}=\text { area of non-prestressed reinforcement, } \\
\mathrm{A}_{\mathrm{nz}}=\text { area of the face of the nodal zone, } \\
\mathrm{f}_{\mathrm{ce}}=\text { effective compressive strength, } \beta_{\mathrm{s}}, \beta_{\mathrm{n}}=\text { strength } \\
\text { reduction factors for struts and nodes respectively }\end{array}$ \\
\hline 2. & $\begin{array}{c}\text { IS456: } \\
2000\end{array}$ & $\tau_{c}=\frac{0.85 \sqrt{0.85 f_{c k}}}{6 \beta}(\sqrt{(1+5 \beta)}-1)$ & where $\beta=\left(0.8 f_{c k}\right) /\left(6.89 P_{t}\right)$ or 1 , whichever is greater \\
\hline 3. & $\begin{array}{c}\text { BS8110 } \\
(1997)\end{array}$ & $v_{c}=\left[\frac{0.79}{\gamma_{m}}\left(\frac{100 A_{s}}{b_{v} d}\right)^{1 / 3}\left(\frac{400}{d}\right)^{1 / 4}\left(\frac{f_{c u}}{25}\right)^{1 / 3}\left(2 \frac{d}{a_{v}}\right)\right]$ & $\begin{array}{c}\text { Where, } \\
\begin{array}{c}(400 / d)^{1 / 4} \geq 1 ; \rho_{t}=100 A_{s} / b_{v} d \% \leq 3 \\
f_{c u} \leq 40 \mathrm{MPa}\end{array}\end{array}$ \\
\hline 4. & $\begin{array}{l}\text { ACI -318 } \\
(2005)\end{array}$ & $\begin{array}{c}V=V_{c}+V_{s} \text {, where, } V_{c} \\
=\left(3.5-2.5 \frac{M_{u}}{V_{u} d}\right)\left(0.16 \sqrt{f_{c}^{\prime}+17 \rho_{w} \frac{V_{u} d}{M_{u}}}\right) b_{w} d \\
\text { where } V_{u} d / M_{u} \leq 1 ; \text { with } V_{c} \leq 0.29 \sqrt{f_{c}^{\prime} b_{w} d} \\
V_{s}=\frac{A_{v}}{S_{v}}\left[\frac{1+\frac{l_{n}}{d}}{12}\right]+\frac{A_{h}}{S_{h}}\left[\frac{11-\frac{l_{n}}{d}}{12}\right]=\frac{\left(v_{v}-v_{c}\right)}{f_{y}} b\end{array}$ & $\begin{array}{c}\mathrm{f}_{\mathrm{y}} \leq 410 \mathrm{MPa} \\
\mathrm{A}_{\mathrm{v}}=\text { the area of vertical web reinforcement within a } \\
\text { distance } \mathrm{S}_{\mathrm{v}} \text { in inch } \\
\mathrm{A}_{\mathrm{h}}=\text { the area of horizontal web reinforcement within a } \\
\text { distance } \mathrm{S}_{\mathrm{h}} \text { in inch }{ }^{2}\end{array}$ \\
\hline 5. & $\begin{array}{c}\text { EC2 - } \\
2004\end{array}$ & $v_{n}=0.18\left(1+\frac{\sqrt{200}}{d}\right)\left(100 \rho_{w} f_{c k}\right)^{0.33}$ & where $f_{c k}=f_{c u}-1.6$. \\
\hline 6. & AIK (1998) & $V_{n}=0.18\left(10+\frac{l_{n}}{d}\right) \sqrt{f_{c k}} b_{w} d$ & where $2 \leq l_{n} / d \leq 5$. \\
\hline 7. & $\begin{array}{l}\text { Zsutty } \\
(1968)\end{array}$ & $v_{u}=\left(\frac{2.5}{\frac{a}{d}}\right)\left[2.3\left(f_{c}^{\prime} \rho \frac{d}{a}\right)^{0.333}\right]$ & where $\frac{a}{d}<2.5$ \\
\hline
\end{tabular}

Table 2: Data on deep beams without shear reinforcement

\begin{tabular}{|c|c|c|c|c|c|c|c|c|c|c|c|c|c|}
\hline Properties & No. & b & $(\mathrm{mm})$ & \multicolumn{2}{|c|}{ h (mm) } & \multicolumn{2}{|c|}{ d (mm) } & \multicolumn{2}{|c|}{$\mathbf{a} / \mathbf{d}$} & \multicolumn{2}{|c|}{ fc'(MPa) } & \multicolumn{2}{|c|}{$\rho w(\%)$} \\
\hline Database & & Min. & Max. & Min. & Max. & Min. & Max. & Min. & Max. & Min. & Max. & Min. & Max. \\
\hline Salamy et al (2005) & 12 & 240 & 720 & 475 & 1505 & 400.0 & 1400.0 & 0.5 & 1.5 & 23.0 & 37.0 & 2.0 & 2.1 \\
\hline Ramadan et al. (2011) & 18 & 250 & 250 & 400 & 700 & 360.0 & 660.0 & 1.0 & 2.0 & 37.5 & 37.5 & 0.7 & 1.8 \\
\hline Londhe (2011) & 19 & 100 & 100 & 150 & 400 & 125.0 & 375.0 & 1.1 & 2.0 & 24.4 & 36.7 & 0.3 & 2.4 \\
\hline Mathey\&Watsein (1963) & 16 & 203 & 203 & 457 & 457 & 403.0 & 403.0 & 1.3 & 1.3 & 22.0 & 27.0 & 0.8 & 3.1 \\
\hline Moody et al (1954) & 12 & 178 & 178 & 610 & 610 & 533.0 & 533.0 & 1.1 & 1.1 & 18.0 & 25.0 & 1.7 & 4.3 \\
\hline Lehwalter, (1988) & 4 & 250 & 250 & 200 & 1000 & 160.0 & 930.0 & 1.3 & 1.3 & 14.0 & 19.0 & 1.7 & 2.1 \\
\hline Leonhardt\&Walter (1964) & 1 & 190 & 190 & 320 & 320 & 270.0 & 270.0 & 1.1 & 1.1 & 21.0 & 21.0 & 1.5 & 1.5 \\
\hline Placas (1969) & 3 & 152 & 152 & 305 & 305 & 272.0 & 272.0 & 2.0 & 2.0 & 34.0 & 34.0 & 0.8 & 2.2 \\
\hline Vollum\& Tay (2001) & 10 & 100 & 100 & 200 & 200 & 180.0 & 180.0 & 1.1 & 1.2 & 25.0 & 44.0 & 1.3 & 2.2 \\
\hline Reyes de Ortiz (1993) & 5 & 150 & 150 & 400 & 400 & 326.0 & 363.0 & 1.1 & 1.4 & 32.0 & 51.0 & 1.8 & 2.1 \\
\hline Smith\&Vantsiotis (1982) & 3 & 102 & 102 & 356 & 356 & 305.0 & 305.0 & 1.2 & 1.8 & 20.0 & 22.0 & 1.9 & 2.6 \\
\hline Chen et al (2001) & 4 & 140 & 140 & 500 & 1750 & 444.0 & 1559.0 & 1.5 & 1.6 & 39.0 & 44.0 & 2.6 & 2.6 \\
\hline Tan et al (1997) & 1 & 102 & 102 & 500 & 500 & 443.0 & 443.0 & 1.4 & 1.4 & 78.0 & 78.0 & 1.0 & 1.0 \\
\hline Clarke (1951) & 5 & 203 & 203 & 457 & 457 & 390.0 & 390.0 & 1.3 & 1.7 & 24.0 & 25.0 & 1.0 & 1.0 \\
\hline de Cossio\&Siess (1960) & 1 & 152 & 152 & 457 & 457 & 390.0 & 390.0 & 1.4 & 1.4 & 21.0 & 21.0 & 1.3 & 1.3 \\
\hline Sagaseta (2008) & 2 & 135 & 135 & 500 & 500 & 438.0 & 438.0 & 1.1 & 1.1 & 68.0 & 80.0 & 3.3 & 3.3 \\
\hline Total Tests & 116 & & & & & & & & & & & & \\
\hline
\end{tabular}




\section{International Journal of Science and Research (IJSR) \\ ISSN (Online): 2319-7064}

Index Copernicus Value (2013): 6.14 | Impact Factor (2013): 4.438

Table 3: Data on deep beams with Shear reinforcement

\begin{tabular}{|c|c|c|c|c|c|c|c|c|c|c|c|c|c|c|c|c|c|c|c|}
\hline Properties & No & $\mathrm{b}$ & $(\mathrm{mm})$ & $\mathrm{h}(\mathrm{mm})$ & \multicolumn{2}{c|}{$\mathrm{d}(\mathrm{mm})$} & \multicolumn{2}{c|}{$\mathrm{a} / \mathrm{d}$} & \multicolumn{2}{c|}{$\mathrm{fc}^{\prime}(\mathrm{MPa})$} & \multicolumn{3}{c|}{$\rho_{t}(\%)$} & \multicolumn{2}{c|}{$\rho_{v}(\%)$} \\
\hline Database & & Min & Max & Min & Max & Min & Max & Min & Max & Min & Max & Min & Max & Min & Max \\
\hline Ahmad et al (2011) & 6 & 150 & 150 & 375 & 525 & 318.8 & 467.5 & 0.6 & 0.9 & 34.0 & 34.0 & 0.5 & 1.0 & 1.5 & 2.1 \\
\hline Salamy et al (2005) & 8 & 240 & 840 & 475 & 1505 & 400.0 & 1400.0 & 0.5 & 1.5 & 23.5 & 37.8 & 2.0 & 2.1 & 0.4 & 0.8 \\
\hline Brena\& Roy (2009) & 12 & 152 & 155 & 356 & 635 & 303.0 & 581.0 & 1.0 & 2.0 & 27.0 & 35.4 & 0.4 & 0.7 & 1.0 & 1.0 \\
\hline Londhe (2010) & 9 & 100 & 100 & 400 & 400 & 375.0 & 375.0 & 1.1 & 1.1 & 32.1 & 32.2 & 0.6 & 2.4 & 0.5 & 2.3 \\
\hline Rao\& Prasad (2010) & 12 & 150 & 150 & 300 & 1200 & 252.0 & 1105.0 & 0.8 & 0.8 & 29.2 & 32.0 & 1.5 & 1.5 & 0.2 & 0.2 \\
\hline Lehwalter, (1988) & 1 & 250 & 250 & 600 & 600 & 460.0 & 460.0 & 1.3 & 1.3 & 17.0 & 17.0 & 2.0 & 2.0 & 1.5 & 1.5 \\
\hline Tan et al., (1995) & 1 & 110 & 110 & 500 & 500 & 463.0 & 463.0 & 1.3 & 1.3 & 51.0 & 51.0 & 1.9 & 1.9 & 0.4 & 0.4 \\
\hline Regan (1971) & 6 & 152 & 152 & 305 & 305 & 254.0 & 272.0 & 1.1 & 1.7 & 17.0 & 44.0 & 1.9 & 2.4 & 0.3 & 0.5 \\
\hline Tan et al., (1997) & 2 & 110 & 110 & 500 & 500 & 433.0 & 433.0 & 1.4 & 1.4 & 35.0 & 35.0 & 3.2 & 3.2 & 0.4 & 0.5 \\
\hline Vollum\& Tay (2001) & 2 & 100 & 100 & 200 & 200 & 180.0 & 180.0 & 1.1 & 1.1 & 34.0 & 51.0 & 2.6 & 2.9 & 0.6 & 1.2 \\
\hline Clarke (1951) & 27 & 152 & 203 & 381 & 457 & 314.0 & 390.0 & 1.3 & 1.7 & 14.0 & 78.0 & 2.4 & 3.1 & 0.2 & 1.1 \\
\hline Kong\&Rangan (1998) & 2 & 250 & 250 & 350 & 350 & 292.0 & 292.0 & 1.1 & 1.6 & 89.0 & 89.0 & 3.2 & 3.2 & 0.1 & 0.8 \\
\hline Sagaseta (2008) & 6 & 135 & 135 & 500 & 500 & 438.0 & 438.0 & 1.1 & 1.1 & 68.0 & 80.0 & 3.2 & 3.2 & 0.2 & 0.5 \\
\hline Total Tests & 94 & & & & & & & & & & & & & & \\
\hline
\end{tabular}

Table 4: Average Margin of Safety for predicting the shear capacity of RC Deep beams without Shear Reinforcement

\begin{tabular}{|c|c|c|c|c|c|}
\hline No. & Model & $\begin{array}{c}\text { No. of Beams used for } \\
\text { Evaluation }\end{array}$ & $\begin{array}{c}\text { Average Margin of } \\
\text { Safetv (AMS) }\end{array}$ & $\begin{array}{c}\text { Standard Deviation } \\
\text { (STDEV) }\end{array}$ & $\begin{array}{c}\text { Coeff. of } \\
\text { Variation (CV) }\end{array}$ \\
\hline 1. & ACI 318-08 (STM) & 116 & 1.1 & 0.4 & 0.36 \\
\hline 2. & IS:456 (2000) & 116 & 4.5 & 1.7 & 0.38 \\
\hline 3. & Zsutty (1968) & 116 & 0.4 & 0.2 & 0.50 \\
\hline 4. & BS 8110, 1997 & 116 & 4.4 & 0.4 & 0.41 \\
\hline 5. & ACI 318-05 & 116 & 0.8 & 0.8 & 0.40 \\
\hline 6. & EC2-04 & 116 & 1.9 & 0.2 & 0.42 \\
\hline 7. & AIK-98 & 116 & 0.4 & & 0.50 \\
\hline
\end{tabular}

Table 5: Average Margin of Safety for predicting the shear capacity of RC Deep beamswith Shear Reinforcement

\begin{tabular}{|c|c|c|c|c|c|}
\hline No. & Model & $\begin{array}{c}\text { No. of Beams used for } \\
\text { Evaluation }\end{array}$ & $\begin{array}{c}\text { Average Margin of } \\
\text { Safety (AMS) }\end{array}$ & $\begin{array}{c}\text { Standard Deviation } \\
\text { (STDEV) }\end{array}$ & $\begin{array}{c}\text { Coeff. of Variation } \\
\text { (CV) }\end{array}$ \\
\hline 1. & ACI 318-08 (STM) & 94 & 1.3 & 0.5 & 0.38 \\
\hline 2. & IS:456 (2000) & 94 & 6.4 & 2.5 & 0.39 \\
\hline 3. & Zsutty (1968) & 94 & 0.5 & 0.2 & 0.40 \\
\hline 4. & BS 8110, 1997 & 94 & 6.0 & 2.5 & 0.41 \\
\hline 5. & ACI 318-05 & 94 & 0.6 & 0.5 & 0.83 \\
\hline 6. & EC2-04 & 94 & 2.9 & 1.3 & 0.45 \\
\hline 7. & AIK-98 & 94 & 0.6 & 0.3 & 0.50 \\
\hline
\end{tabular}

prediction for the deep beams with shear reinforcement in terms of accuracy, economy and safety (Table 5). With the lowest average margin of safety of 1.3, the [7] STM model has proved to give closer average predictions to the experimental average compared to the [51], [18] and [11] which generated AMS of 2.9, 6.0 and 6.4 respectively. These other models can be said to be overly conservativesince they produced very high AMS in excess of 1.

Also, in terms of shear strength prediction uniformity, the [7] STM continued to produce the lowest CV of 0.38 , compared with [11], [18] and [51] which recorded CV values of 0.39 , 0.41 and 0.45 respectively for the beams with shear reinforcement (Table 5). This shows that in terms of prediction uniformity, the [7] STM is more reliable than the rest of the models for the beams with shear reinforcement.

The [46], [52] and [53] design models again over-estimated the shear strength of deep beams with shear reinforcement, since they presented AMS of $0.6,0.6$ and 0.5 respectivelywhich are below unity. This implies that predicted strength values are far greater than the actual strength obtained from experiments which connotes danger to design.
The high accuracy and uniformity of the predictions of the shear strength of deep beams, with and without shear reinforcement, given by the [7] STM provision could be attributed to the fact that, unlike the others, the model measures the actual strength of the compressive struts formed by the internal tied-arch mechanism which conveys the load directly to the supports at failure. The conservativeness of the three code models, namely; [51], [18] and [11], for the prediction of both beams with and without shear reinforcement can be attributed to the fact that they represent equations developed for slender beams which have been modified with a shear enhancement factor of $2 \mathrm{~d} / \mathrm{a}$.This is applicable whenan applied point load is within two effective depths from the face of the support of the beam, as proffered by these codes. Thus, the effectiveness of the [7] STM shear strength provision over the other models is well established.

\section{Conclusions and Recommendations}

Definition of a deep beam, as captured by different codes of practice and standards, were discussed to find the most realistic definition for the characterization of deep beams. Also, comparative study amongst seven models for predicting the shear resistance of deep beams was carried out 


\section{International Journal of Science and Research (IJSR) \\ ISSN (Online): 2319-7064 \\ Index Copernicus Value (2013): 6.14 | Impact Factor (2013): 4.438}

in the study to find the predictive efficiency of each model. The following conclusions can be drawn from the analysis:

- Deep beams are normally defined on two bases: The [7] concept and the [11] concept. The [7] concept definition is based on two parameters: geometrical consideration and loading condition, whereas the [11] concept definition only accounts for geometry.

- The [7] concept definition of a deep beam accounts for all plausible scenarios where D-regions occur on the beam. The presence of D-regions on a beam is the major characteristic for the classification of a deep beam, as it creates non-linear strains in the beam which is the most critical behaviour of deep

- beams. This suggests that the [7] concept definition is the most reliable definition of deep beams and hence, must be adopted to characterize deep beams.

- Shear strength of a deep beam is affected by factors such as shear span-to-depth ratio, concrete compressive strength, longitudinal reinforcement, beam web reinforcement, beam depth, beam span-to-depth ratio and type of concrete. However, shear span-to-depth ratio is the most significant factor that affects the shear strength of a deep beam followed by the vertical shear reinforcement.

- The [7] strut-and-tie model (STM) has proved to be the most economical and safe model for the prediction of shear strength of deep beams, with or without shear reinforcement, in the study. This is because it produced the lowest estimate of the Average margin of safety just above 1 and the lowest Co-efficient of Variation, and hence gives predictions with the highest uniformity. This suggests that the [7] strut-and-tie model is the most effective model for the prediction of the shear strength of RC deep beams and hence, must be employed in their design.

- The other equations of [46],[52] and [53] proved to overestimate the shear capacity of deep beams which could be harmful to the design of deep beams.

\section{References}

[1] Ghugal, Y. M. and Dahake A.G. (2012). Flexural analysis of deep beam subjected to parabolic load using refined shear deformation theory. Applied and Computational Mechanics 6 (2012) 163-172.

[2] Niranjan, B.R. and Patil, S. S. (2012). Analysis of R.C Deep Beam by Finite Element Method. International Journal of Modern Engineering Research (IJMER). Vol. 2, Issue. 6, Nov.-Dec. 2012, pp-4664-4667. ISSN: 2249-6645.

[3] Rao G. A. and Sundaresan, R. (2012). Evaluation of size effect on shear strength of reinforced concrete deep beams using refined strut-and-tie model. Sadhana Vol. 37, Part 1, February 2012, pp. 89-105. Indian Academy of Sciences.

[4] Tan, K. H. and Cheng, G. H. (2006). Size effect on shear strength of deep beams: Investigation with strutand-tie model", J. Struct. Eng., 132(5), 673-685.

[5] Breña, S. F. and Roy, N. C. (2009). Evaluation of Load Transfer and Strut Strength of Deep Beams with Short Longitudinal Bar Anchorages. ACI Structural Journal. Technical paper. Title no. 106-S63.

[6] Rogowsky, D. M., MacGregor, J. G. \&Ong, S. Y. (1983). Tests of Reinforced Concrete Deep Beams. University of Alberta, Edmonton. Report number: 109.
[7] ACI-318, (2008). Building Code Requirements for Structural Concrete (ACI 318-08) and Commentary. American Concrete Institute.

[8] Ahmad, S. H. S. Rafeeqi F.A. and Fareed F. (2011). Shear Strength of Normal and Light Weight Reinforced Concrete Deep Beams without Web Reinforcement. Journal of Emerging Trends in Engineering and Applied Sciences (JETEAS) 2 (6): 967-971.

[9] Shuraim, A. B. (2012). Behavior and shear design provisions of reinforced concrete D-region beams. Journal of King Saud University - Engineering Sciences, (2013) Vol. 25, pp. 65-74.

[10] Kong F. K. (2011). Reinforced Concrete Deep Beam ${ }^{\text {ee }}$, Van No strand Reinhold, New York.

[11] IS-456 (2000). Indian standard code of practice for plain and reinforced concrete for general buildingconstruction", Bureau of Indian Standards, New Delhi, India.

[12] CSA Committee A23.3 (2004). Đesign of Concrete Structures: Structures (Design)—A National Standard of Canada." Canadian Standards Association.

[13] Seo, S.-Y. Yoon S.-J. and Lee W.-J. (2004). Structural behavior of $\mathrm{R} / \mathrm{C}$ deep beam with headed longitudinal reinforcements. 13th World Conference on earthquake engineering. Vancouver, B.C., Canada, August 1-6, 2004. Paper no. 58.

[14] Londhe, R. S. (2011). "Shear strength analysis and prediction of reinforced concrete transfer beams in high-rise buildings." Structural Engineering Mechanics, 37(1), 39-59.

[15] Ley, T.M., Riding, K.A., Widianto, Bae, S.J. and Breen, J.E. (2007). Experimental verification of strutand-tie model design method", ACI Struct. J., 104(6), 749-755.

[16] Zhang N. and Tan K. H. (2007). Size effect in RC deep beams: experimentalinvestigation and STM verification. Engineering Structures29(12): 3241-3254.

[17] Sagaseta, J. and Vollum, R. L. (2008). Strut-and-tie modelling of short span beams. Proceedings of fib International Symposium 2008, Tailor made concrete structures, Amsterdam, 19-22, ISBN-13: 978-0-41547535-8.

[18] BS 8110 (1997), Structural use of concrete-part 1: code of practice for design and construction", British Standard Institution, Milton Keynes, London.

[19] Smith, K. H. and Vantsiotis, A. S., (1982), Shear strength of deep beams," ACI JOURNAL, Proceedings, 79(3): 201- 213.

[20] Manuel, R. F., Slight, B. W., and Suter, G. T. (1971). "Deep beam behavior affected by length and shear span vibrations." ACI Structural Journal, 68(12), 954-958.

[21] Mau, S. T. and Hsu, T. T. C. (1989). Formula for shear strength of deep beams, ACI Structural Journal, Vol.86, No. 5, 1989. pp.516-523.

[22] Tan, K. H. Kong, F. K. Teng, S. and L. Guan (1995). High Strength Concrete Deep Beams with Effective Span and Shear Span Variations," ACI Structural Journal, V. 92, No. 4, July-Aug. 1995, pp. 395-405.

[23] Ashour, A. F., Alvarez, L. F., and Toropov, V. V. (2003). "Empirical modeling of shear strength of RC deep beams by genetic programming." Computers and Structures, 81(5), 331-338.Bazant Z.P. and Oh, B.H. (1984); Crack band theory for fracture of concrete. Mat and Strs, 16(93):155-177. 


\section{International Journal of Science and Research (IJSR) \\ ISSN (Online): 2319-7064 \\ Index Copernicus Value (2013): 6.14 | Impact Factor (2013): 4.438}

[24] Collins, M. P. and Mitchell, D. (1991). Prestressed Concrete Structures. New Jersey, Prentice Hall.

[25] Kani G. N. J. (1967). Basic Facts Concerning Shear Failure. Journal of ACI, 1966, pp. 675-692.

[26] Shioya, T. S., (1989). Shear Properties of Large Reinforced Concrete Member, Special Report of Institute of Technology, Shimizu Corporation, No. 25, February 1989, 213 pp.

[27] Yang, K.H., Chung, S.H. and Ashour, A.F. (2007). Influence of section depth on the structural behaviour of reinforced concrete continuous deep beams", Mag. Concrete Res., 59(8), 575-586.

[28] Tan, K. H., Cheng, G. H. and Zhang, N. (2008), Experiment to mitigate size effect on deep beams", Mag. Concrete Res., 60(10), 709-723.

[29] RaoG. A. and Sundaresan, R. (2012). Evaluation of size effect on shear strength of reinforcedconcrete deep beams using refined strut-and-tie model. SadhanaVol. 37, Part 1, February 2012, pp. 89-105.Indian Academy of Sciences.

[30] Walsh, P.F. (1972). Fracture of plain concrete. The Indian Concrete J. 46(11): 469-476.

[31] Yang, K. Chung, H. Lee, E. Eun, H. (2003). Shear characteristics of high-strength concrete deep beams without shear reinforcements. EnggStrs 25: 1343-1352.

[32] Rao, G. A. and Kunal, K. (2007). Shear strength of RC deep beams. Eligehausen, University of Stuttgart, 70569 Stuttgart, Germany.Rao A. G. and Kunal, K. (2007). Shear strength of RC deep beams. Indian Institute of Technology Madras, Chennai-600 036, In.

[33] Hillerborg, A., Modeer, M., and Petersson, P.E., (1976). - Aalysis of Crack Formation and Crack Growth in Concrete by Means of Fracture Mechanics and Finite Elements," Cement and Concrete Research, 6, 773-782.

[34] Bazant, Z.P. and Oh, B.H. (1983). Crack band theory for fracture of concrete. Mat and Strs, 16(93):155-177.

[35] Jenq, Y. and Shah, S.P. (1985). Two parameter fracture model for concrete. Jl. of EngMech 111(10): 12271240.

[36] Bazant Z.P. and Kim J.K, (1984): Size effect in shear failure of longitudinally reinforced beams". ACI J 1984; 81:456-68

[37] Shahnewaz M. (2013). Shear behavior of reinforced concrete deep beams under static and dynamic loads. A thesis submitted in partial fulfillment of the requirements for the degree of Master of Applied Science in the College of Graduate Studies (Civil Engineering), the University of British Columbia (Okanagan), May, 2013.

[38] Clark, A. P. (1951). "Diagonal tension in reinforced concrete beams." American Concrete Institude Journal, 23(2), 145-156.

[39] Kong, F.; Robins, P. J.; and Cole D. F. (1970). Web Reinforcement Effects on Deep Beams," ACI Journal, No. 67, December 1970, pp. 1010-1018.

[40] Oh, J. K. and Shin, S. W. (2001), Shear strength of reinforced concrete deep beams", Struct. J., 98(2), 164173.

[41] Quintero-Febres, C., Parra-Montesinos, G., and Wight, J. K. (2006). "Strength of struts in deep, concrete members designed using strut-and-tie method." ACI Structural Journal, 103(4), 577-586.
[42] Choi Y. W. Lee H. K. Chu S. B. Cheong S. H. and Jung W. Y. (2012). Shear Behavior and Performance of Deep Beams Made with Self-Compacting Concrete. International Journal of Concrete Structures and Materials, Vol.6, No.2, pp.65-78, June 2012.

[43] Yang K-H and Ashour A. F. (2010). Aggregate interlock in lightweight concrete continuous deep beams. Journal of Engineering Structures, Vol. 33, pp.136-145

[44] El-Sayed, A.K., (2006) -Concrete contribution to the shear resistance of FRP-reinforced concretebeams" PhD Thesis, University of Sherbrooke, Sherbrooke, Quebec, Canada. Eurocode EC2 (2004). European Committee for Standardization, EN1992-1-1:2004 NO002 (2002), Đesign of concrete structures, Part 1: General rules and regulations for buildings", English Edition, British Standards Institution, London.

[45] Mohammadhassani M. Jumaat M. Z. Ashour, A. F. and Jameel, M. (2011). Failure modes and serviceability of high strength self-compacting concrete deep beams. Journal of Engineering Failure Analysis, Vol. 18 (2011), pp. 2272-2281.Mau, S.T. and Hsu, T.T.C. (1987). Shear strength prediction for deep beams with webreinforcement. Am. Concr. Inst. Struct. J. 84, 6: 513.

[46] ACI 318-05; ACI Committee 318, Building code requirements for structural concrete (ACI 318-2005) and commentary (318R-2005), American Concrete Institute (ACI).

[47] AppaRao G. and Kunal K. (2007). Shear strength of Reinforced Concrete deep beams. FraMOS-6, 17-22, June, 2007, Catania, Italy, pp. 671-675.

[48] Omeman, Z. Nehdi, M. and El-Chabib, H. (2008). Experimental study on shear behavior of carbon-fiberreinforced polymer reinforced concrete short beams without web reinforcement. Canadian Journal of Civil Engineering, 35(1), 1-10.

[49] Brown M. D. and Bayrak, O. (2006). Minimum transverse reinforcement for bottle-shaped struts, ACI STRUCTURAL JOURNAL, Vol.103, No.6, 2006. pp.813-821.

[50] Khaldoun, R. and Khaled, A. (2004). Minimum transverse reinforcement in $65 \mathrm{MPa}$ concrete beams. ACI StrJl 101(6):872-878.

[51] Eurocode 2, (2004). Design of Concrete Structures, Part 1-1: General Rules and Rules for Buildings. 2004-1-1, p. 230.

[52] Architectural Institute of Korea (AIK) Code (2000). Reinforced Concrete Design Code and Examples. Gimoondang. Seoul.R.O.K.

[53] Zsutty T, (1986): Beam Shear Strength Prediction by Analysis of Existing Data". ACI Journal 65(11): 942951.

[54] Afrifa R. O. (2013). Performance evaluation of shear strength of reinforced concrete beams made from phylliteaggregates. A Thesis submitted to the Department of Civil Engineering, KNUST, Kumasi, in partial fulfillment of the requirement for the degree of Doctor of Philosophy. Department of Civil Engineering, College of Engineering. 